\title{
Assessment of mite fauna in different coffee cropping systems in Brazil
}

\section{Marília Lara Peixoto, Leda Gonçalves Fernandes, Matheus Araújo Cardoso} Carvalho, Milena Leite de Oliveira, Fernando Ferrari Putti \& André Rodrigues dos Reis

To cite this article: Marília Lara Peixoto, Leda Gonçalves Fernandes, Matheus Araújo Cardoso Carvalho, Milena Leite de Oliveira, Fernando Ferrari Putti \& André Rodrigues dos Reis (2017) Assessment of mite fauna in different coffee cropping systems in Brazil, Biocontrol Science and Technology, 27:3, 424-432, DOI: 10.1080/09583157.2017.1296931

To link to this article: https://doi.org/10.1080/09583157.2017.1296931

$$
\text { Published online: } 28 \text { Feb } 2017 .
$$

\section{Submit your article to this journal $\square$}

LIIl Article views: 75

View Crossmark data ¿ 


\title{
Assessment of mite fauna in different coffee cropping systems in Brazil
}

\author{
Marília Lara Peixoto ${ }^{a}$, Leda Gonçalves Fernandes ${ }^{b}$, Matheus Araújo Cardoso Carvalho ${ }^{a}$, \\ Milena Leite de Oliveira ${ }^{c}$, Fernando Ferrari Putti ${ }^{\mathrm{a}, \mathrm{c}}$ and André Rodrigues dos Reis ${ }^{\mathrm{c}, \mathrm{d}}$

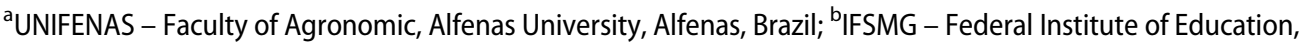 \\ Science, and Technology in Minas Gerais Southern, Machado, Brazil; 'UNESP - São Paulo State University, \\ Tupã, Brazil; dUNESP - São Paulo State University, Ilha Solteira, Brazil
}

\begin{abstract}
Agro-ecological diversification may increase natural biodiversity and decrease environmental impacts caused by the intensification of management practices, especially with respect to pest control. This study aimed to evaluate mite populations from surveys in commercial coffee (Coffea arabica) orchards managed in different ways. Four different cropping systems were compared: a conventional system (CS), non-pesticide system (NPS), organic system (OS) and organic agroforestry system (OAS). Mite samples were taken from 24 coffee plantations $(n=6$ for each management strategy). Six leaves per plant were collected from five sampling sites totalling 30 leaves from each plantation. Mites were removed from individual leaves, counted and identified to family level. Amongst the predatory mites, two families were detected; the Phytoseiidae was the most abundant family while the Stigmaeidae, generalist predatory mites, were only found in two management systems (NPS and AOS). Of the two families of phytophagous mites, the family Tenuipalpidae was the most abundant, but rarely found in AOS. The other phytophagous family, Tetranychidae, was less abundant in coffee crops than Tenuipalpidae, but the most abundant phytophagous family in CS. Understanding the relationship between mite populations and management practices can aid in choice of spraying strategies for different coffee management systems.
\end{abstract}

\section{ARTICLE HISTORY}

Received 30 March 2016

Returned 6 February 2017

Accepted 14 February 2017

\section{KEYWORDS}

Phytophagous; predatory mites; biodiversity;

sustainability

\section{Introduction}

Coffee cultivation in Brazil is of great economic and social importance. In 2014 national coffee production was 2712 million $\mathrm{kg}$ of which 70.5\% was Coffea arabica and $29.5 \%$ was Coffea canephora (Alves, Goulart, Jacobson, de Miranda Filho, \& Ribas, 2016). Fragmentation of natural ecosystems for the production of crop monocultures causes loss of important natural habitats essential for the conservation of biodiversity (De Beenhouwer, Aerts, \& Honnay, 2013; Dias, Zanetti, Santos, Louzada, \& Delabie, 2008). In fact, conceptual models in agriculture suggest that the implementation of extensive areas of monocultures

CONTACT Fernando Ferrari Putti $\otimes$ fernandoputti@tupa.unesp.br $\Theta$ UNESP e São Paulo State University, Postal Code 17602-496, Tupã, SP, Brazil

(C) 2017 Informa UK Limited, trading as Taylor \& Francis Group 
has negatively impacted natural resources, including natural enemies that contribute to the regulation of insect-pest populations (Ceja-Navarro et al., 2015).

The regular occurrence of pests, year after year, reduces productivity and the quality of coffee. Phytophagous mites are considered one of the most important pests causing significant damage to coffee plants in Brazil (Duarte, Navia, dos Santos, Rideiqui, \& Silva, 2015; Oliveira, Ferreira, Oliveira, Santos, \& Pallini, 2014). According to Reis, Souza, Souza, and Teodoro (2000) Tetranychidae, Tenuipalpidae and Tarsonemidae mites are the key arthropod pests in coffee orchards. With respect to predatory mites, the family Phytoseiidae is widely and commonly found in a range of different coffee management systems.

One of the alternatives to the conventional production model is the adoption of organic agricultural practices, with techniques that improve sustainability of agro-ecosystems. Many growers meeting organic certification standards use biofertilisers to enhance plant nutrition. Some of these biofertilisers have recognised acaricidal and insecticidal activity (Tuelher, Venzon, Guedes, \& Pallini, 2014). Pest population surveys are important for an in-depth understanding of life history traits, valuable information for making pest control decision (Gliessman, 2013; Vera Castillo et al., 2014).

There is a lack of information about the mite families occurring in commercial coffee orchards in Brazil. The goal of this study is to provide information on mite populations occurring in different coffee management production systems. This information is a powerful tool enabling farmers to make informed decisions on pesticide selection that are appropriate for different coffee management systems.

\section{Material and methods}

\subsection{Study areas and sampling methodology}

Twenty-four commercial coffee orchards under four different management strategies ( $n=$ 6 orchards per strategy) were considered: a conventional system (CS); non-pesticide system (NPS); organic system (OS) and an organic agroforestry system (OAS). All orchards evaluated were of the same age and cultivar characteristics: 16 orchards were in Campo do Meio city, Minas Gerais State, Brazil (21 $06^{\prime} 24^{\prime \prime}$ S; $45^{\circ} 49^{\prime} 49^{\prime \prime}$ W; altitude: $785 \mathrm{~m})$ and 8 were in Guapé city, Minas Gerais State, Brazil (20 $45^{\prime} 42^{\prime \prime}$ S; $45^{\circ} 55^{\prime} 03^{\prime \prime}$ W; altitude: $760 \mathrm{~m}$ ). For all orchards evaluated, the mean annual rainfall and temperature range were $1590 \mathrm{~mm}$ and $14.3-26.9^{\circ} \mathrm{C}$, respectively. In each coffee orchard, we surveyed an area of approximately $2500 \mathrm{~m}^{2}$ that had been selected using a GPS device. The experimental design was completely randomised. Mites from each orchard were sampled from 6 leaves on each of 5 plants totalling 30 leaves per orchard. From each orchard the collected leaves were placed in a plastic bag and transported to the Laboratory of Entomology (Unifenas University - Alfenas Campus) for further taxonomic evaluation.

\subsection{Taxonomic analysis}

Leaves from each sample were washed as described by Spongoski, Reis, and Zacarias (2005) to extract mites. Briefly, $500 \mathrm{~mL}$ of deionised water and 3 drops of detergent were added in each sample of leaves in a plastic bag. The bag was shaken for approximately 
$15 \mathrm{~s}$, the leaves removed and the resulting liquid passed through a $325-\mu \mathrm{m}$ mesh, retaining the suspended mites. The mites were placed into $30-\mathrm{mL}$ glass flasks and preserved in $70 \%$ alcohol. All mites from each sample were transferred to microscope slides in Hoyer's medium (Flechtmann, 1989) and identified to family using the dichotomous keys of Marchetti (2008) under light microscopy. The total number of mites and abundance of each mite family was recorded for each sample.

\subsection{Statistical analysis}

Analysis of variance (ANOVA) was used to assess the abundance of each mite family in the different coffee management systems. Differences in means were compared using the Kruskall-Wallis test in Minitab and Sigmastat software (Putti et al., 2015). Cluster analysis was done to determine similarity amongst the families recorded between the management strategies.

\section{Results and discussion}

The highest mean number of mites per leaf (total - all families) was observed in the CS (7.5 mites), although statistically, this was not significantly different $(p \leqq .05)$ to the mean number of mites in the OAS (5.25 mites) or the NPS (3.71 mites) (Table 1). The fewest mites were recorded in the OS $(2.17$ mites $)$ and this was significantly lower than the number in the CS $(p \leqq .05)$ (Table 1$)$.

The highest mite abundances observed in the CS could be due to the constant application of neonicotinoid insecticides (Mineiro et al., 2006). This happens because neonicotinoid insecticides remove natural enemies of mites. Similar results have been observed by de Toledo, Reis, da Silveira, de Marafeli, and de Souza-Pimentel (2013). According to Fernandes (2013), OASs for coffee production in Southern Minas Gerais State, Brazil had a greater abundance and diversity of mites which they attributed to a greater capacity for conservation of natural enemies (such as predatory mites), healthy soil as a result of high plant biodiversity. In NPSs, it is common to observe the proliferation of weeds which can act as a reservoir for mites, particularly predatory mites (Mineiro et al., 2006). The adoption of agroforestry systems that include a range of other crops and non-crop habitats alongside coffee can also harbour phytophagous mites, which in turn can enhance predatory mite numbers (Monteiro, 2002).

When considering the abundance of mites within particular families, irrespective of management strategy, we found mites from just four families: Phytoseiidae (predatory

Table 1. Mean abundance of mites (all families) per leaf in different coffee management systems.

\begin{tabular}{lc}
\hline Management system & Number of mites $^{\mathrm{a}}$ \\
\hline Conventional system & $7.5 \pm 2.88 \mathrm{~A}$ \\
Organic agroforestry system & $5.25 \pm 9.22 \mathrm{AB}$ \\
Organic system & $2.17 \pm 4.83 \mathrm{~B}$ \\
Non-pesticide system & $3.71 \pm 2.75 \mathrm{AB}$ \\
C.V. (\%) & 46.61 \\
\hline
\end{tabular}

Note: Means followed by the same letter in the column are not statistically significantly different from each other using the Kruskal-Wallis test ( $5 \%$ probability).

${ }^{\mathrm{a}}$ Data for the mean number of mites were mathematically transformed by $\sqrt{x+0.5}$.

Abbreviation: \pm indicate the average standard deviation from six replicates; C.V.: coefficient of variation. 
Table 2. Mean abundance of Phytoseiidae, Stigmaeidae, Tenuipalpidae and Tetranychidae per leaf from coffee orchards.

\begin{tabular}{lc}
\hline Family & Number of mites $^{\mathrm{a}}$ \\
\hline Phytoseiidae & $18.5 \pm 3.7 \mathrm{~A}$ \\
Stigmaeidae & $0.5 \pm 0.57 \mathrm{C}$ \\
Tenuipalpidae & $8.75 \pm 7.5 \mathrm{AB}$ \\
Tetranychidae & $1.25 \pm 1.89 \mathrm{BC}$ \\
C.V. (\%) & 59.68 \\
\hline
\end{tabular}

Note: Means followed by the same letter in the column are not statistically significantly different from each other using the Kruskal-Wallis test (5\% probability).

${ }^{a}$ Data for the mean number of mites were mathematically transformed by $\sqrt{x+0.5}$.

Abbreviation: \pm indicate the average standard deviation from six replicates; C.V.: coefficient of variation.

mites), Tenuipalpidae (phytophagous mites), Tetranychidae (phytophagous mites) and Stigmaeidae (predatory mites). Overall, members of the Phytoseiidae were the most abundant (18.5 mites per plant) although this was not statistically different $(p \leqq .05)$ from numbers of the Tenuipalpidae ( 8.75 mites per plant), followed by the families, Tetranychidae (1.25 mites per plant) and finally, the least abundant, Stigmaeidae (0.5 mite per plant) (Table 2).

Matos, Pallini, Chaves, and Galbiati (2004) have shown that mites from the family Phytoseiidae take advantage of domatia which occur in the leaves of coffee shrubs, and serve as reproduction sites for this family of predatory mites resulting in their relatively high abundance in coffee; this may account for why they were the most abundant family on coffee in our study, and more abundant than plant feeding mites. The presence of adjacent plant diversity in integrated coffee cultivation systems also provides shelter for predatory Phytoseiidae (Silva, Reis, Zacarias, \& Marafeli, 2010). As in our study, Reis, Teodoro, and Pedro Neto (2000) observed high populations of phytophagous mites from the family Tenuipalpidae on coffee in South of Minas Gerais, particularly during the driest period and at mild temperatures. Silva et al. (2010) also reported high densities of phytophagous Tenuipalpidae, and lower densities of Tetranychidae, as we observed during dry season; Tetranychidae are economically important pests in coffee, even in low populations (Reis, Souza, et al., 2000). Low abundances of mites in the families Tetranychidae and Stigmaeidae have also been reported by Spongoski et al. (2005) in coffee in the Cerrados area of Brazil. Predatory mites from the family Stigmaeidae were observed in the current study and probably contribute to biological control in coffee. The same family was also reported by Spongoski et al. (2005) in Patrocínio city, Minas Gerais State, Brazil and by Mineiro et al. (2006) in the Garça and Jeriquara regions of São Paulo State, Brazil. It is possible that the greater number of phytophagous mites present from the Tenuipalpidae contributes to a wider diversity of predatory mites. According to Matioli, Ueckermann, and de Oliveira (2002) and Matioli and de Oliveira (2007), this occurs because there is a greater oviposition rate of predatory mites when they feed on Brevipalpus phoenicis (a common phytophagous mite from the family Tenuipalpidae in coffee), compared to other prey.

The relative abundance of each of the four families identified was compared between each management system. The Phytoseiidae was the most abundant family in all management systems (Figure 1) but also varied between the different management systems. This is similar to the study of Mineiro et al. (2006) who reported high variation in the abundance of Phytoseiidae in different crop management systems. Our results regarding variation in 


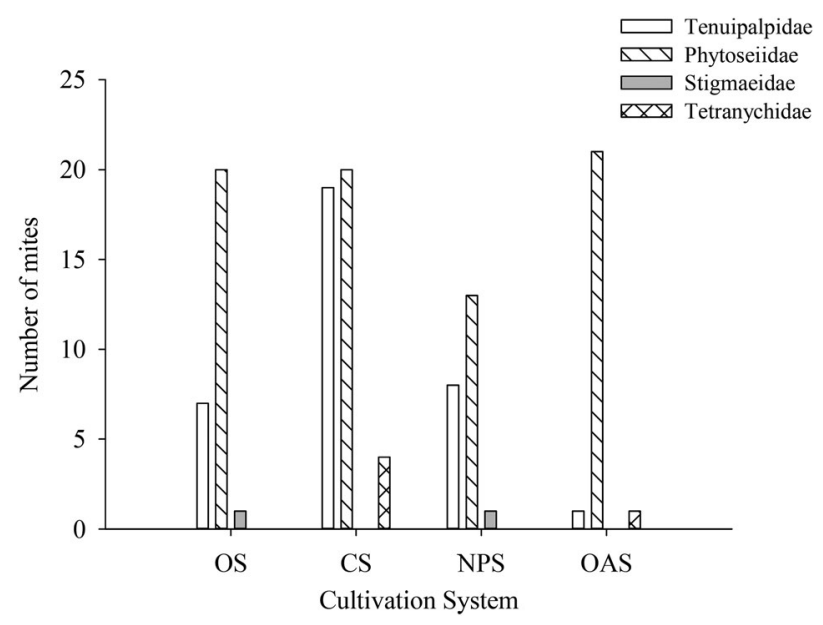

Figure 1. Total number of individual mites per sample from different families sampled from four coffee management systems: CS, OS, NPS and OAS.

the abundance of Phytoseiidae from organic and conventional management systems corroborate Mineiro et al. (2006). In our study the OAS had the greatest abundance of Phytoseiidae, followed by the CS and OS. The Tenuipalpidae (the second-most abundant family) were most abundant in the CS, followed by the NPS, OS and finally the OAS. Tetranychidae (the third-most abundant family) was only recorded in the CS (its highest abundance), and the OAS, whereas the Stigmaeidae family was only recorded in the OS and the NPS (Figure 1). Mite species collected in this study are illustrated in Figure 2.

Rainfall significantly affects the number of predatory (Phytoseiidae and Stigmaeidae) and phytophagous mites (Tenuipalpidae and Tetranychidae) in a range of crop management systems (Neto, Reis, Silva, Zacarias, \& Mesquita, 2010). For this reason, the low rate of rainfall during the sampling period may have caused the high abundance of phytophagous mites in the current study, in which Phytoseiidae and Tenuipalpidae were present in all treatments.

According to Mineiro et al. (2006), several species of Phytoseiidae are specialists and feed only on mites or micro-arthropods found in natural vegetation. Other species of Phytoseiidae are more generalist in their feeding habits and also feed on pollen, nectar or other compounds secreted by plants, and other prey, which may contribute to their high abundance in all evaluated cultivation systems.

The Tenuipalpidae had the highest abundance of all phytophagous mites, regardless of the cultivation system (Mineiro, Sato, Raga, Souza Filho, \& Spongoski, 2008). Fernandes (2013) reported mites from Tenuipalpidae in agroforestry-managed coffee which was different to our study showing low rates in the agroforestry system. According to Neto et al. (2010), the overall number of mites was smaller in coffee plantations based on an organic management system than in CSs. They suggested this was because there was a better balance of fauna, provided by neighbouring plants, in the OS compared to the CS. However, we found even lower numbers of mites in the agroforestry system than the OS and possibly due to the presence of arboreal plants between rows, providing an even better pollen source to support predatory mites than the OS. According to Fernandes 


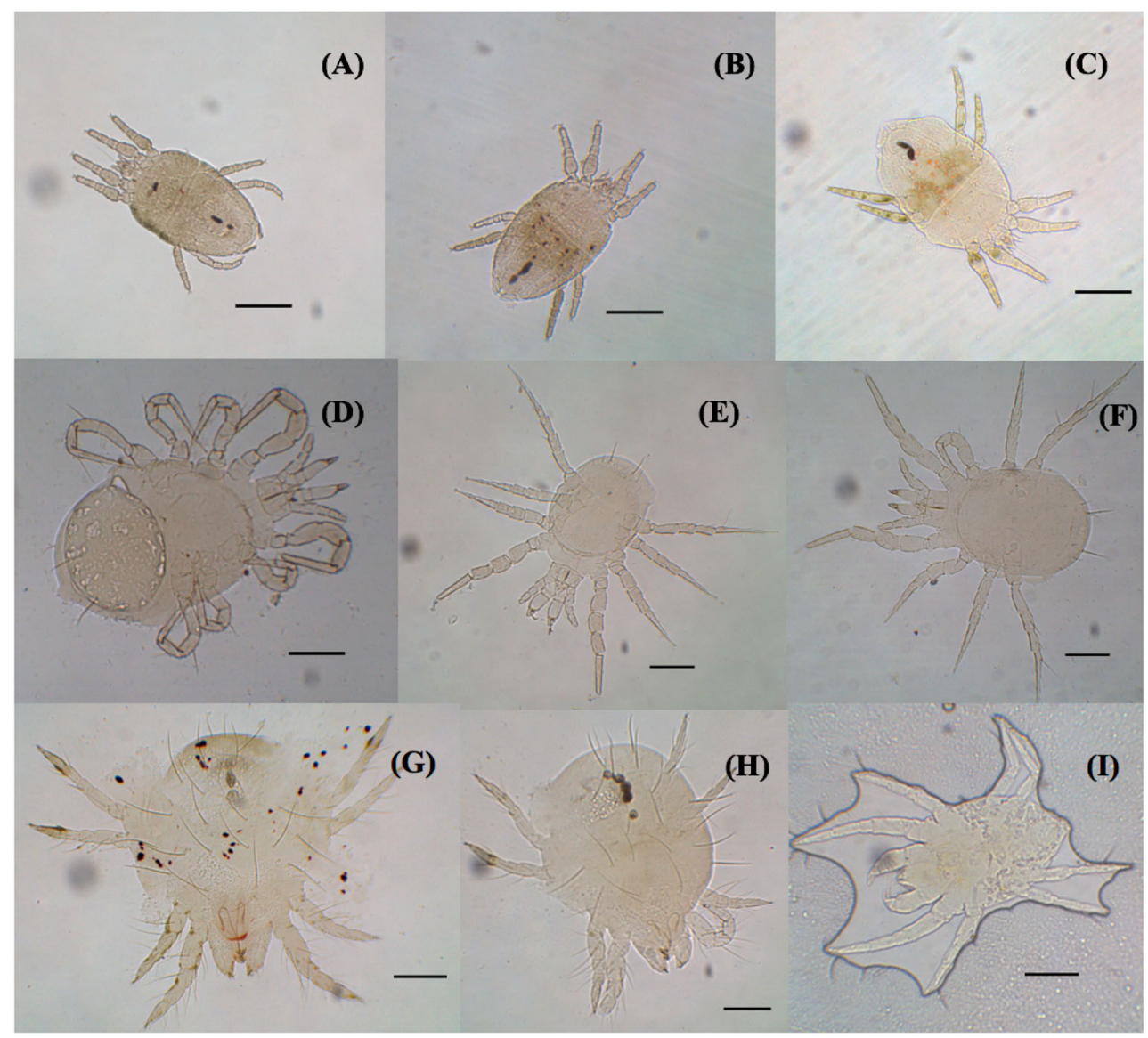

Figure 2. Photographs of individual mites from the families Tenuipalpidae (A, B and C), Phytoseiidae (D, E and F), Tetranychidae ( $\mathrm{G}$ and $\mathrm{H}$ ) and Stigmaeidae (I) observed in this study. The scale bars indicate $0.1 \mathrm{~mm}$.

(2013), interactions between the coffee plantation and adjacent arboreal plants maintain predatory mites in the coffee and increase their activities preventing significant increases in pest mites during the most favourable periods. Mineiro et al. (2006) and Neto et al. (2010) also reported that the family Tetranychidae, the second-most abundant phytophagous mite in coffee plantations, was more abundant in conventional cultivation systems than in NPSs, as we also demonstrated. It is worth noting that competition between the predatory families (Phytoseiidae and Stigmaeidae) mentioned by Fernandes (2013) may also explain the low numbers of Stigmaeidae that we observed.

Our data have revealed a great diversity of mite fauna in coffee plantations and that their populations are influenced by management practices. Less-aggressive practices in agro-ecosystems, such as the employment of organic and agroforestry systems, or their integration, favour the predatory mite fauna resulting in a subsequent decrease in damage caused by phytophagous mites. Further studies on taxonomy, behaviour and ecology are necessary in order to provide better strategies to maintain the fauna balance. 


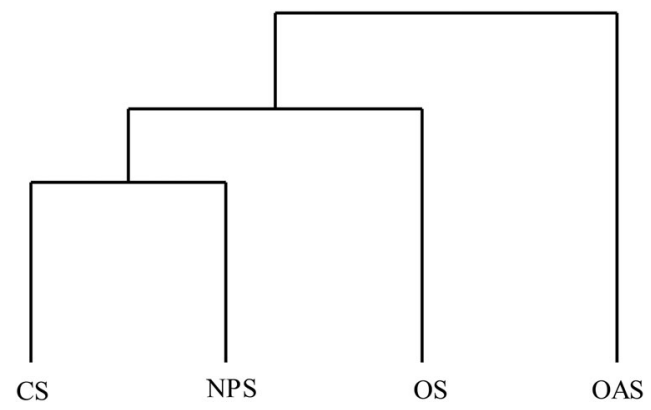

Figure 3. Dendrogram from cluster analysis of similarity in mite abundance and identity (families present) amongst the different coffee management systems: CS, OS, NPS and OAS.

In the cluster analysis, the conventional management system had the greatest similarity (77.67\%) with NPSs, followed by $65.49 \%$ similarity with the OS. The OAS had the least similarity $(60.08 \%)$ with any other coffee management system (Figure 3 ).

The high similarity between the CS and the NPS is probably due to the fact that these two systems are most similar. The similarity between CS and NPSs is the application of chemical fertiliser via soil or foliar to enhance the plant mineral nutrition (Fernandes 2013). These results highlight that these systems had the lowest mite species richness. This happens because OASs have high vegetation biodiversity, which can facilitate the dissemination of several mite families.

\section{Conclusion}

A total of four mite families were recorded, including Phytoseiidae which was the most abundant predatory mite family in coffee cultivations. In contrast the family Stigmaeidae, containing generalist predatory mites, was only found in small numbers and in just two management systems (the NPS and OAS). The Tenuipalpidae was the most abundant family of phytophagous mites and only rarely occurred in the OAS. The Tetranychidae were the second-most abundant phytophagous family of mites in coffee cultivation and most abundant in the CS.

\section{Disclosure statement}

No potential conflict of interest was reported by the authors.

\section{References}

Alves, V., Goulart, F. F., Jacobson, T. K. B., de Miranda Filho, R. J., \& Ribas, C. E. D. C. (2016). Shade's benefit: Coffee production under shade and full sun. Journal of Agricultural Science, 8 (11), 11-19.

Ceja-Navarro, J. A., Vega, F. E., Karaoz, U., Hao, Z., Jenkins, S., Lim, H. C., \& Brodie, E. L. (2015). Gut microbiota mediate caffeine detoxification in the primary insect pest of coffee. Nature Communications, 6, 1-9. 
De Beenhouwer, M., Aerts, R., \& Honnay, O. (2013). A global meta-analysis of the biodiversity and ecosystem service benefits of coffee and cacao agroforestry. Agriculture, Ecosystems \& Environment, 175, 1-7.

Dias, N. S., Zanetti, R., Santos, M. S., Louzada, J., \& Delabie, J. (2008). Interação de fragmentos florestais com agroecossistemas adjacentes de café e pastagem: Respostas das comunidades de formigas (Hymenoptera, Formicidae). Iheringia, Série Zoologia, 98(1), 136-142.

Duarte, M. E., Navia, D., dos Santos, L. R., Rideiqui, P. J., \& Silva, E. S. (2015). Mites associated with sugarcane crop and with native trees from adjacent Atlantic forest fragment in Brazil. Experimental and Applied Acarology, 66(4), 529-540.

Fernandes, L. G. (2013). Diversidade de inimigos naturais de pragas do cafeeiro em diferentes sistemas de cultivo (Doctoral thesis). Universidade Federal de Lavras (UFLA), Lavras, MG, Brazil.

Flechtmann, C. H. W. (1989). Ácaros de importância agrícola (6th ed.). São Paulo: Nobel, p. 189.

Gliessman, S. (2013). Coffee, coffee rust, and the need for agroecological diversification. Agroecology and Sustainable Food Systems, 37(7), 737-738.

Marchetti, M. M. (2008). Ácaros do cafeeiro em Minas Gerais com chave de identificação (Dissertation thesis). Universidade Federal de Viçosa, Viçosa, MG, Brazil.

Matioli, A. L., \& de Oliveira, C. A. (2007). Biologia de Agistemus brasiliensis Matioli, Ueckermann \& Oliveira (Acari: Stigmaeidae) e sua potencialidade de predação sobre Brevipalpus phoenicis (Geijskes) (Acari: Tenuipalpidae). Neotropical Entomology, 36, 577-582.

Matioli, A. L., Ueckermann, E. A., \& de Oliveira, C. A. L. (2002). Some stigmaeid and eupalopsellid mites from citrus orchards in Brazil (Acari: Stigmaeidae and Eupalopsellidae). International Journal of Acarology, 28(2), 99-120.

Matos, C. H., Pallini, A., Chaves, F. F., \& Galbiati, C. (2004). Do coffee domatia benefit the predatory mite Iphiseiodes zuluagai Denmark \& Muma (Acari: Phytoseiidae)? Neotropical Entomology, 33(1), 57-63.

Mineiro, J. D. C., Sato, M. E., Raga, A., Souza Filho, M. D., \& Spongoski, S. (2008). Incidência de ácaros em cafeeiro cv. Catuaí Amarelo. Bragantia, 67(1), 197-201.

Mineiro, J. L. D. C., Sato, M. E., Raga, A., Arthur, V., Moraes, G. D., Sarreta, F. D. O., \& Carrijo, A. (2006). Diversidade de ácaros (Arachnida: Acari) em Coffea arabica L. cv. Mundo Novo, nos municípios de Jeriquara e Garça, Estado de São Paulo. Biota Neotropica, 6(2), 1-15.

Monteiro, L. B. (2002). Manejo integrado de pragas em macieira no Rio Grande do Sul II. Uso de Neoseiulus californicus para o controle de Panonychus ulmi. Revista Brasileira de Fruticultura, 24(2), 395-405.

Neto, M. P., Reis, P. R., Silva, R. A., Zacarias, M. S., \& Mesquita, D. N. (2010). Influência do regime pluviométrico na distribuição de ácaros em cafeeiros conduzidos em sistemas orgânico e convencional. Coffee Science, 5(1), 67-74.

Oliveira, C. M., Ferreira, J. A., Oliveira, R. M., Santos, F. O., \& Pallini, A. (2014). Ricoseius loxocheles, a phytoseiid mite that feeds on coffee leaf rust. Experimental and Applied Acarology, 64 (2), 223-233.

Putti, F. F., Gabriel Filho, L. R. A., Klair, A. E., Silva Junior, J. F., Ludwig, R., \& Cremasco, C. P. (2015). Response of lettuce crop to magnetically treated irrigation water and different irrigation depths. African Journal of Agricultural Research, 10, 2300-2308.

Reis, P. R., Souza, J. D., Souza, E. O., \& Teodoro, A. V. (2000). Spatial distribution of Brevipalpus phoenicis (Geijskes) (Acari: Tenuipalpidae) in coffee plants (Coffea arabica L.). Anais da Sociedade Entomológica do Brasil, 29(1), 177-183.

Reis, P. R., Teodoro, A. V., \& Pedro Neto, M. (2000). Predatory activity of phytoseiid mites on the developmental stages of coffee ringspot mite (Acari: Phytoseiidae: Tenuipalpidae). Anais da Sociedade Entomológica do Brasil, 29(3), 547-553.

Silva, E. A., Reis, P. R., Zacarias, M. S., \& Marafeli, P. P. (2010). Fitoseídeos (Acari: Phytoseiidae) associados a cafezais e fragmentos florestais vizinhos. Ciência e Agrotecnologia, 34(5), 1146-1153.

Spongoski, S., Reis, P. R., \& Zacarias, M. S. (2005). Acarofauna da cafeicultura de cerrado em Patrocínio, Minas Gerais. Ciência e Agrotecnologia, 29, 9-17.

de Toledo, M. A., Reis, P. R., da Silveira, E. C., de Marafeli, P., \& de Souza-Pimentel, G. C. (2013). Predatory potential of Euseius alatus (Phytoseiidae) on different life stages of Oligonychus ilicis 
(Tetranychidae) on coffee leaves under laboratory conditions. Neotropical Entomology, 42(2), 185-190.

Tuelher, E. S., Venzon, M. M., Guedes, R. N. C., \& Pallini, A. (2014). Toxicity of organic-coffee mite Oligonychus ilicis and to its predator Iphiseiodes zuluagai. Crop Protection, 55, 28-34.

Vera Castillo, Y. B., Pritchard, H. W., Frija, A., Chellattan Veettil, P., Sanchez, J. C., Van Damme, P., \& Van Huylenbroeck, G. (2014). Production viability and farmer's willingness to adopt Jatropha curcas L. as a biofuel source in traditional agroecosystems in Totonacapan, Mexico. Agricultural Systems, 125, 42-49. 